\title{
Håndrotsbrudd - på tide med ny praksis!
}

Det forekommer om lag 20000 brudd i hånden hvert år i Norge (1). Til sammenlikning diagnostiseres henimot 15000 brudd i distale radius og 9000 i proksimale femur. Skader i håndroten har vært en diagnostisk utfordring for mang en ung lege på røntgenavdelingen på vakttid når man står der og studerer de mange små knoklene i håndroten, på jakt etter mulig fraktur. Legestudenter er i alle år blitt fortalt om de diagnostiske vanskelighetene med å påvise brudd, og at man derfor skal gipse på mistanke (2).

I dette nummer av Tidsskriftet får vi presentert to studier om denne problematikken $(3,4)$. Det hyppigste bruddet i håndroten er i os scaphoideum og rammer oftest unge menn $(1-3)$. Forholdet mellom brudd i distale radius og i os scaphoideum er om lag 10:1. Skademekanismen er stort sett den samme, fall mot utstrakt hånd. Til sammen utgjør bruddene på hver side av håndleddet henimot $25 \%$ av alle brudd.

Det har vært et mantra når det gjelder skafoidfraktur at tidlig behandling er vesentlig dersom man skal ha håp om tilheling. Studien fra Haugesund bekrefter dette på en overbevisende måte (3). En slik praksis kommer imidlertid ikke uten omkostninger (4). Er det riktig å fortsette å gipse håndroten bare på mistanke om skafoidfraktur - for å garantere behandling i tide? Hvor mange unødvendige gipsinger, unødvendige sykmeldinger og bekymrede pasienter skal vi ha på samvittigheten, før noen prøver å løse dette problemet en gang for alle?

I en studie fra Gjøvik påviser forfatterne at 89 pasienter i yrkesaktiv alder (18-66 år) ble gipset i totalt 187 uker uten å ha brudd i båtbeinet. Det samme gjaldt henimot 50 skoleungdommer i løpet av de fem-seks årene undersøkelsen omfatter. Forfatterne beskriver ikke hvor stort befolkningsgrunnlaget er i Gjøvik-området, men vi snakker i alle fall om 4-5 årsverk som går tapt på grunn av sykmelding og unødvendig gips (4). Hva kan gjøres for å unngå en slik kostbar praksis? MR av håndroten påviser skafoidfraktur med en spesifisitet og sensitivitet på ca. $100 \%$ (4). Man trenger ikke engang foreta en full undersøkelse for å få svar på om det foreligger fraktur. Kun enkelte sekvenser (STIR og T1) i ett plan er tilstrekkelig for å bekrefte/avkrefte mistanken. Undersøkelsen kan derfor gjøres på noen minutter, innimellom andre mer tidkrevende undersøkelser. Spørsmålet om man skal utføre CT eller MR på mistanke om skafoidfraktur dukker opp på de fleste kurs i frakturkirurgi. Til det er å si at MR er klart det beste når det gjelder å avklare hvorvidt det foreligger brudd eller ikke. CT gir derimot bedre informasjon om frakturens omfang og type, og er klart å foretrekke hvis man skal operere en skafoidfraktur eller vurdere om den har tilhelet (5).

En nylig publisert studie fra Australia (6) støtter konklusjonen i studien fra Gjøvik, nemlig at tidlig MR er konstnadseffektivt sammenliknet med ukelang gipsbehandling kun på klinisk mistanke om skafoidfraktur (4). Det er derfor sunne indikasjoner for at man også i Norge bør tilrettelegge forholdene slik at man på avdelinger der man behandler skafoidfrakturer, kan få tatt MR ved mistanke om brudd, og derved unngå den kostnadskrevende praksis med unødvendig gipsing.

Spørsmålet om operativ behandling omtales også i studien fra Haugesund (3), hvor man på dislokerte brudd gjorde åpen reposisjon og intern fiksasjon. Dette er helt i tråd med dagens praksis i Norge. Brudd som er dislokert, eller har en diastase mellom fragmentene på mer enn $1 \mathrm{~mm}$, anbefales operert. De fleste skafoidfrakturer er stabile (ikke-dislokerte) og blir derfor gipset. Ulempen er imidlertid at disse bruddene gror sent, og mange pasienter må ha gips i tre måneder eller mer. Ved gipsbehandling av ikke-dislokerte brudd har man en tilhelingsrate på $87-97 \%$.

Tidlig i 1980-årene utførte vi de første operasjonene i Norge med den nye «hodeløse» skruen spesielt designet for skafoidkirurgi. Denne første generasjonen Herbert-skruer som ikke var kannelert, måtte settes inn med en uhåndterlig jigg etter åpen reposisjon. Metoden var teknisk vanskelig og slo derfor ikke an i Norge. Nå er tredje eller fjerde generasjons skruer for skafoidkirurgi kommet, som perkutan teknikk med kannelerte, «hodeløse» skruer. Operasjonen tar 15-30 minutter og pasientene starter bevegelsestrening umiddelbart, som alternativ til 6-16 uker med gips. Flere internasjonale studier har vist at det er kostnadseffektivt med perkutan kirurgi (dagkirurgi) også til ikke-dislokerte brudd $(7,8)$. Skafoidfrakturen sammenliknes ofte med lårhalsbrudd på grunn av den særegne karforsyningen hos en del pasienter med dårlig vaskularisering til det proksimale fragmentet. Som kjent kan lårhalsbrudd også behandles med sengeleie i tre måneder. Men slik behandling anses i dag som uetisk, og resultatene etter operativ behandling er langt å foretrekke. Randomiserte studier av skafoidfrakturer har vist at tidlig perkutan operasjon, også av ikke-dislokerte skafoidfrakturer, fører til bedre tilheling ( $100 \%$ av frakturene i flere studier), kortere sykmeldingstid og kortere tid før man kan gjenoppta sportslige aktiviteter $(7,8)$. De to artiklene i dette nummer av Tidsskriftet $(3,4)$ gir en klar pekepinn om at det kan være på tide å revidere rutinene i Norge når det gjelder diagnostikk og behandling ved klinisk mistanke om skafoidfraktur.

\section{Leiv M. Hove}

leiv.hove@helse-bergen.no

Leiv Hove (f. 1948) er spesialist i kirurgi, plastikkirurgi, ortopedisk kirurgi og håndkirurgi. Han er professor i ortopedisk kirurgi ved Universitetet i Bergen og overlege ved Haukeland universitetssykehus.

\section{Oppgitte interessekonflikter: Ingen}

\section{Litteratur}

1. Hove LM. Fractures of the hand. Distribution and relative incidence. Scand J Plast Reconstr Hand Surg 1993; 27: 317-9.

2. Larsen CF. Acute wrist trauma. An epidemiological, radiographic and clinical investigation; with special reference to fracture of the scaphoid and carpal instability. Doktoravhandling. Odense: Odense Universitet, 1992.

3. Valen B. Behandling av fraktur i handrota. Tidsskr Nor Lægeforen 2009; 129 183-5.

4. Furunes H, Vandvik PO. Gips ved mistanke om skafoidfraktur. Tidsskr Nor Lægeforen 2009; 129: 177-9.

5. Adey L, Souer JS, Lozano-Calderon S. Computed tomography of suspected scaphoid fractures. J Hand Surg 2007; 1: 61-6

6. Brooks S, Cicuttini FM, Lim S et al. Cost effectiveness of adding magnetic resonance imaging to the usual management of suspected scaphoid fractures. Br J Sports Med 2005; 39: 75-9.

7. Davis EN, Chung KC, Kotsis SV et al. A cost/utility analysis of open reduction and internal fixation versus cast immobilization for acute nondisplaced mid-waist scaphoid fractures. Plast Reconstr Surg 2006; 117: 1223-35.

8. McQueen MM, Gelbke MK, Wakefield A et al. Percutaneous screw fixation versus conservative treatment for fractures of the waist of the scaphoid. J Bone Joint Surg Br 2008; 90: 66-71. 